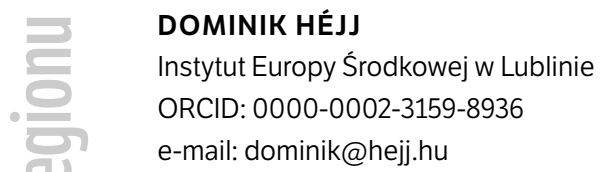

\title{
Czy bez dostępu do morza Węgry przyłączą się do Trójmorza?
}

Will Hungary join to the Three Seas Initiative without access to their 'own sea'?

Słowa kluczowe:

Węgry, Inicjatywa Trójmorza, polityka zagraniczna
Keywords:

Hungary, Three Sees

Initiatice, foreign affairs 
Will Hungary join to the Three Seas Initiative without access to their 'own sea'?

The Three Sees Initiative (TSI) enables cooperation of the twelve states clustered between three seas - the Baltic, Adriatic and Black Seas. The TsI's priorities include projects related to the development of road and energy infrastructure, as well as taking measures to increase the region's competitiveness. The purpose of this article is to indicate the conditions related to the Hungarian perception of the TSI and to define the factors enabling closer cooperation under the TSI and those that impede this cooperation. The analysis is based on the latest findings, which make it possible to track changes in Hungary's perception of the TSI. 
7 agadnienie obecności Węgier w Inicjatywie Trójmorza (Three Sees -Initiative - TSI, węg. Három Tenger Kezdeményezés) podejmowałem dotychczas dwukrotnie. Po raz pierwszy w „Polskim Przeglądzie Dyplomatycznym" ${ }^{1}$ i po raz drugi w „Roczniku Instytutu Europy Środkowej”" Jest to temat wciąż niewyczerpany, a każda następna refleksja dotycząca stosunku węgierskiego rządu do TSI ewoluuje wspólnie z polityczną agendą Budapesztu. O ile Węgry jeszcze pod koniec 2019 r. nie były członkiem Funduszu Trójmorza, o tyle ten stan rzeczy zmienił się zasadniczo w maju 2020 r. wraz z ich decyzją o dołączeniu do Funduszu. Uzasadnione wydaje się zatem kontynuowanie rozważań, uzupełniając je o nowe wątki. W tym artykule uwaga zostanie skupiona na wskazaniu elementów, które z perspektywy Węgier przemawiałyby za pogłębioną integracją z TSI, a zarazem przyczyniają się do zachowania wobec niej pewnego dystansu.

\section{Uwarunkowania wstępne}

Węgry nie były dotychczas (i nie są obecnie) państwem aktywnie zaangażowanym w Inicjatywę Trójmorza. Chociaż odbyły się cztery szczyty Inicjatywy Trójmorza, to prezydent János Áder, reprezentujący państwo węgierskie, pojawił się na nich tylko dwukrotnie - w 2016 r. w Dubrowniku i w 2017 r. w Warszawie. Przed dwoma laty, w 2018 r., prezydent Węgier do Rumunii nie dotarł z powodu kłopotów lotniczych ${ }^{3}$. Oficjalną podaną przyczyną była kolizja jego samolotu z autem obsługi lotniskowej podczas kołowania na budapeszteńskim lotnisku Ferihegy. Prezydenta zastąpił ambasador Węgier w Rumunii. W 2019 r. z kolei Áder w ogóle nie udał się do stolicy Słowenii, co nieoficjalnie przewidywano od dawna. Przebywał w tym czasie z wizytą w Siedmiogrodzie, w Rumunii. Do Lublany poleciał Péter Szijjártó, minister spraw zagranicznych i handlu zagranicznego.

1 D. Héjj, Trójmorze - nowy instrument w polskiej polityce zagranicznej, „Polski Przegląd Dyplomatyczny" 2017, nr 4, s. 68-78.

2 Tenże, The Three Seas Initiative in the foreign affairs policy of Hungary, [w:] „Rocznik Instytutu Europy Środkowo-Wschodniej", Lublin 2019, t. 17, z. 3, s. 115-135. DOI: 10.36874/RIESW.2019.3.7.

3 Komunikat Węgierskiej Agencji Prasowej, MTI [online], 18 IX 2018 [dostęp: 6 VII 2020], dostępny w internecie: 〈https://archiv1988tol.mti.hu/Pages/HirSearch.aspx>. 
Piąty szczyt TSI odbył się w Tallinie w dniach 12-13 października 2020 r., lecz z powodu pandemii coviD-19 przybrał on formę zdalną.

Zagadnienie Inicjatywy Trójmorza nie jest obecne w naukowym piśmiennictwie węgierskim. Dostępne są wprawdzie dwa opracowania teoretyczne ${ }^{4}$, lecz porównując je z literaturą dostępną w Polsce, nie są to teksty, które wyczerpywałyby zagadnienie TSI. To bardziej eseje aniżeli kompleksowe studia wypełnione jakimikolwiek danymi. Z jednej strony kładą akcent na dominującą rolę Polski w tym projekcie i w żaden sposób nie wyczerpują tematu ani nie przedstawiają go jako priorytetowego $\mathrm{w}$ polityce zagranicznej Węgier. Autorzy skupiają się głównie na niepowodzeniach Inicjatywy Trójmorza (np. opóźnieniach w realizacji projektu Via Carpatia). Charakterystyczne, że także węgierskie elity polityczne odpowiedzialnością za niepowodzenia związane z dotrzymywaniem terminów poszczególnych realizacji obarczają pozostałe kraje zaangażowane $\mathrm{w} \mathrm{TSI}^{5}$.

Inicjatywa Trójmorza, co interesujące, kojarzona jest z Polską i jej znaczącą rolą w tym projekcie. Podkreśla się, że TSI to projekt zmierzający do budowania strategicznej pozycji i roli Polski w regionie. Węgierskie władze mają świadomość tego, że TSI jest jednym z priorytetów polskich władz. Węgrzy w czasie wspólnych spotkań dlatego najczęściej zapewniają o swoim poparciu dla tej inicjatywy. W 2018 r. Viktor Orbán, udzielając wywiadu polskiej telewizji publicznej, podkreślał m.in. znaczenie TSI. Do TSI odwoływał się także minister spraw zagranicznych i handlu zagranicznego Szijjártó przy okazji prezentacji planów Polskich Linii Lotniczych LOT w związku z propozycją utworzenia w porcie lotniczym w Budapeszcie hubu przesiadkowego. Plany te mogą obecnie ulec rewizji z powodu następstw ekonomicznych związanych z pandemią COVID-19.

4 B. Tölgyesi, A Három tenger kezdeményezés és az Intermarium koncepció háttere és kilátásai. The background and perspectives of the Three Seas Initiative and the Intermarium Concept, „KKI-elemzések” E-2017/30 [online], dostępny w internecie [dostęp: 6 VII 2020]: 〈https://kki.hu/assets/upload/30_KKI-elemzes_POL_ Tolgyesi_20171121.pdf>; J.T. Barabás, A Három Tenger Kezdeményezés a 2018. szeptemberi Bukaresti értekezlet után. The Three Seas Initiative after the Bucharest summit of september 2018, „KKI ELEMZÉSEK” E-2018/34 [online], dostępny w internecie [dostęp: 6 VII 2020]: 〈https://kki.hu/assets/upload/34_KKI-elemzes_TSI_ Barabas_20181016.pdf $>$.

5 J. T. Barabás, A Három Tenger Kezdeményezés..., s. 5. 
Wskazując na wyzwania stojące przed TSI, Bartosz Wiśniewski, ówczesny analityk PISM, podkreślał, że jej instytucjonalnym ograniczeniem jest przeniesienie ciężaru decyzyjnego TSI na prezydentów. Stanowi to trudność z powodu różnic $w$ systemach politycznych poszczególnych państw członkowskich oraz pozycji głowy państwa. Ma to również znaczenie w przypadku Węgier, sygnalizując stosunek Budapesztu do TSI. Uwarunkowania związane z systemem politycznym umożliwiają prowadzenie jednocześnie określonej gry wobec tej inicjatywy.

Relacja ustrojowa między prezydentem a premierem marginalizuje pozycję prezydenta, sprowadzając jego obowiązki zasadniczo do wypełniania wyłącznie funkcji reprezentacyjnych. O ile prezydent Węgier, reprezentując państwo, udaje się na spotkania z udziałem głów państw, o tyle faktyczną politykę w kraju prowadzi premier dysponujący w zakresie polityki zagranicznej nieograniczonymi kompetencjami. Na najważniejsze dla Węgier spotkania jeździ premier, nie prezydent. Przykładem tego typu politycznej zależności był udział prezydenta w konferencji klimatycznej w Paryżu w 2015 r. Do stolicy Francji udał się wówczas János Áder, a premier Węgier Viktor Orbán w tym samym czasie prowadził negocjacje w stolicy Iranu, Teheranie, na temat współpracy w dziedzinie energetyki atomowej, gdyż z jego perspektywy był to istotniejszy element realizacji polityki zagranicznej Węgier. Konkluzja sprowadza się zatem do tego, że bez autentycznego zaangażowania premiera, a za jego pośrednictwem i całego gabinetu, żadne inicjatywy w sferze polityki zagranicznej nie mają większych szans powodzenia. Dlatego postacią centralną, na której zostanie skupiona uwaga w niniejszym artykule, jest premier Węgier.

Na początku rozważań należy pokrótce odpowiedzieć na pytanie dotyczące priorytetów polityki zagranicznej Węgier. Główna oś zainteresowań tego państwa jest zorientowana przede wszystkim na współpracę z Unią Europejską, mimo że od co najmniej ośmiu lat węgierskie władze czynią wiele, by wśród swoich obywateli pomniejszyć entuzjazm dla integracji europejskiej. Największym partnerem gospodarczym Węgier nadal pozostają Niemcy, a cały wolumen zagranicznej wymiany handlowej z krajami Unii Europejskiej sięga 80 proc. Od niemal dekady rząd węgierski główny akcent kładzie na rozwijanie wymiany handlowej w ramach dwóch doktryn polityki zagranicznej - „otwarcia na Wschód” (węg. keleti nyitás) oraz "otwarcia na Południe” (węg. déli nyitás). Pierwszą inicjatywę ogłoszono na przełomie lat 2011-2012. Wschód stał się partnerem atrakcyjnym, 
gdyż kryzys finansowy dotknął go w nieznacznym stopniu. Nowe rynki zbytu miały napędzić wymianę handlową, ożywić produkcję i aktywność inwestycyjną węgierskich firm, ale także ściągnąć na Węgry inwestorów. Należy pamiętać, że kryzys gospodarczy z 2008 r. bardzo brutalnie doświadczył węgierską gospodarkę. Dług publiczny w latach 2006-2008 wzrósł o 7,3 p.p. do poziomu 73 proc., w ciągu dwóch kolejnych lat (do 2010 r.) o kolejne 9,2 p.p. do poziomu 82,2 proc. Wskaźnik bezrobocia w latach 2007-2010 wzrósł o 4 p.p. do poziomu 11,8 proc. Obligacje skarbu państwa były z kolei oprocentowane w szczytowym momencie na 12,72 proc., giełda zaś uległa załamaniu. W latach 2008-2009 gospodarka zaczęła się kurczyć o 7,80 proc, a PKB per capita spadł o 6,5 proc. $(11749,25$ dol. do 10997,04 dol.) $)^{6}$. Wskaźnik ten do poziomu z 2008 r. powrócił dopiero w 2014 r. Sytuacja państwa stała się dramatyczna - Republice Węgierskiej groziło faktyczne bankructwo.

Zabezpieczeniem przed ewentualnym nowym kryzysem ekonomicznym miały się stać kontakty gospodarcze z krajami Wschodu. Za wyjście z sytuacji uznano decyzję zwiększenia eksportu do krajów spoza Unii Europejskiej do 30 proc. (czego wciąż nie osiągnięto!). Kierunek zmierzający do poszerzenia polityki zagranicznej Węgier o państwa Wschodu dotyczył m.in.: Bałkanów, Chin, Korei Południowej, Rosji, Turcji, krajów arabskich, Iranu, Indii, Singapuru, Wietnamu, Hongkongu i Malezji. Polityka ta od początku skupiła się głównie na współpracy z Chinami, a jej rezultaty można dostrzec np. przy okazji szerzącej się obecnie pandemii coviD-19. Premier Orbán niejednokrotnie podkreśla, że współpraca z Pekinem, „sprawdzonym przyjacielem", zapewniła Węgrom dostawy środków ochronnych do walki z koronawirusem. Poza tym Węgry z Chinami realizują m.in. rewitalizację linii kolejowej Budapeszt-Belgrad, która jest finansowana z kredytu udzielonego przez Chiny, a szczegóły tej inwestycji zostały 19 maja 2020 r. utajnione przez parlament na dekadę ze wzǵlędu na „bezpieczeństwo państwa". Aspiracją Węgier jest konsekwentne przyjęcie roli rzecznika Chin w regionie.

Współpracę z Rosją, skoncentrowaną głównie wokół kwestii energetycznych, utrudniały, a de facto uniemożliwiają, sankcje nałożone na Federację Rosyjską po agresji na Ukrainę i aneksji Krymu (2014 r.). Budowaniu

6 Dane na: „Trading Economics” [online], dostępne w internecie [dostęp: 6 VII 2020]: <http://hu.tradingeconomics.com/hungary $>$. 
i zacieśnianiu relacji sprzyjały przede wszystkim wzajemne wizyty na najwyższym szczeblu państwowym. Udział w nich brali najczęściej premier Węgier oraz minister spraw zagranicznych i handlu zagranicznego - Szijártó. Państwo węgierskie uruchomiło poza tym specjalne linie kredytowe w Exim Banku, z których dotowane są firmy wyrażające chęć współpracy z przedsiębiorstwami wywodzącymi się $\mathrm{z}$ państw uwzględnionych $\mathrm{w}$ doktrynie „otwarcia na Wschód”. Oszacowując skuteczność tej polityki gospodarczej, należy zwrócić uwagę na brak konkretnych danych oceniających bilans tak sformułowanej doktryny polityki zagranicznej. W narracji władz jest ona skuteczna i przynosi konkretne efekty. Zyski czerpane ze współpracy z partnerami ze Wschodu miały równoważyć ograniczenia płynące z sankcji nałożonych na Rosję. Według wypowiedzi ministra Szijjártó dla kanału Rossija24 z września 2018 r. - tzn. tuż po wizycie premiera Orbána wraz $\mathrm{z}$ delegacją w Moskwie - węgierskie firmy miały stracić na sankcjach UE wobec Rosji 8 mld dol. Orbán twierdził wówczas, że największe koszty unijnych sankcji poniosły kraje Europy Środkowej i Wschodniej. Dziennikarze gazety codziennej „Népszava” utrzymywali zaś, że „otwarcie na Wschód” powinno być tłumaczone jako „wschodnia porażka”, skoro w ciągu ośmiu lat deficyt $\mathrm{w}$ handlu zagranicznym $\mathrm{z}$ państwami azjatyckimi niemal się podwoił, wzrastając z 4,6 mld euro do 7,9 mld euro ${ }^{7}$. Dzieje się tak mimo zaangażowania znacznych środków finansowych w napędzanie relacji handlowych, także w otwieranie izb handlowych. Relacje handlowe z najważniejszymi, w odczuciu Węgier, państwami są niesymetryczne i sprowadzają się głównie do udostępnienia własnego rynku dla wschodnich partnerów, jednak bez szans na ich zrównoważenie.

Drugą doktryną w polityce zagranicznej jest "otwarcie na Południe" (węg. déli nyitás). Zgodnie z nią w centrum zainteresowania Węgier znalazły się państwa Ameryki Południowej oraz Afryki. O efektach tej kooperacji wiadomo jeszcze mniej, a trudność wynika stąd, że pojawiają się poważne problemy w dokonaniu ewaluacji obydwu doktryn. Brakuje bowiem na bieżąco aktualizowanych danych odnośnie do skuteczności podejmowanych przez rząd działań w polityce gospodarczej. O „otwarciu na Południe” nie słyszy się w ogóle, chyba że przy okazji oficjalnych wizyt, a „otwarcie na Wschód” szacowane jest przede wszystkim miarą kontaktów z Chinami i Rosją.

7 Zs. Papp, Óriási bukta a keleti nyitás, „Népszava” [online], 17 VIII 2018 [dostęp: 6 VII 2010], dostępny w internecie: 〈https://nepszava.hu/3046858_oriasi-bukta-a-keleti-nyitas〉. 
Z perspektywy niniejszego opracowania ważna jest analiza relacji z Federacją Rosyjską, dlatego temat Chin nie zostanie uwzględniony w rozważaniach.

\section{Czynniki sprzyjające Trójmorzu}

Bilans aktywności Węgier w zakresie TSI jest w zasadzie negatywny. Zaangażowanie Budapesztu $\mathrm{w}$ kooperację $\mathrm{z}$ Trójmorzem sprowadza się głównie do obszaru deklaracji, a nie faktycznych działań. Kwestie, które utrudniają współpracę w ramach Inicjatywy Trójmorza, zostaną przedstawione dalej, ponieważ najpierw należy wskazać elementy sprzyjające temu $\mathrm{w}$ ramach TSI.

Najważniejsza jest ocena determinant gospodarczych związanych z potencjałem ekonomicznym regionu, czyli poziom wzrostu gospodarczego w poszczególnych krajach wchodzących w skład TSI (średni wzrost gospodarczy dwunastki w latach 2017 i 2018 oscyluje w okolicach 4 proc.), oraz niskie wskaźniki bezrobocia. Nie bez znaczenia jest także stabilność polityczna regionu. Pośród dwunastu państw należących do Inicjatywy Trójmorza znajdują się tylko trzy, których udział w imporcie Węgier według danych z 2019 r. jest równy (bądź wyższy) 5 proc. Są to (w kolejności): Austria (6,1 proc.), Polska (5,8 proc.), Czechy (5,0 proc.). Rok wcześniej znajdowała się w tym gronie również Słowacja. Największym partnerem są Niemcy z udziałem na poziomie 25 proc. (29, 4 mld dol., co stanowi spadek o 1 p.p. i 1,1 mld dol. w porównaniu z 2018 r.). W przypadku eksportu, pięcioprocentowym udziałem dysponują, podobnie jak w 2018 r., tylko dwa państwa - Słowacja (5,2 proc.) i Rumunia (5,1 proc.).

Interesująca współpraca natomiast mogłaby się rozwijać w dziedzinie turystyki, co byłoby nie bez znaczenia dla sytuacji ekonomicznej w obliczu pandemii koronawirusa. To ciekawa propozycja, tym bardziej że w opinii węgierskiego premiera turystyka jest przejawem lokalnego patriotyzmu. Podejmowanie wspólnych inicjatyw na rzecz rozwoju turystyki państw Inicjatywy Trójmorza sprzyjałoby zacieśnieniu współpracy i podniesieniu atrakcyjności regionu.

Kolejnym elementem współdziałania jest regionalne budowanie konkurencyjności, czego następstwem powinno być podniesienie atrakcyjności

8 Dane na: „Trading Economics” [online], dostępne w internecie [dostęp: 6 VII 2020]: <http://hu.tradingeconomics.com/hungary $>$. 
inwestycyjnej państw TSI. Jednym z tego przejawów stał się rozwój infrastruktury. Sprzyja to nie tylko zacieśnianiu więzi ekonomicznych czy tranzytowych, lecz służy także poprawie poziomu życia mieszkańców okolic znajdujących się w pobliżu terenów inwestycyjnych. Słabością TSI jest jednak to, że dotychczasowe strategiczne przedsięwzięcia infrastrukturalne nie angażują do projektu wszystkich państw. Węgry zołłaszają m.in. swoje poparcie dla inicjatywy Kolei Dużych Prędkości z Budapesztu do Polski oraz dla rozwoju infrastruktury drogowej w ramach projektu Via Carpatia od miasta Miszkolc do granicy ze Słowacją (w ramach europejskiej drogi E71, a na Węgrzech M30) i dalej do granicy z Rumunią - który ma być gotowy do 2022 r. Znaczne odcinki tej autostrady powstały już dawno, a obecny projekt dotyczy budowy odcinków granicznych. Z priorytetowych planów infrastrukturalnych Węgier wykluczono jednak autostradę M2 z miejscowości Vác (ok. 45 km na północ od Budapesztu), przez miejscowość Hont, aż do granicy w Parassapuszta, w ramach odcinka Gdańsk-Budapeszt i dalej Stambuł (trasa E77) ${ }^{9}$.

Pozytywnie ocenianym wskaźnikiem pogłębiania współpracy w ramach TSI jest powołanie wspólnego indeksu giełdowego - CEEplus, który zainaugurowano we wrześniu 2019 r. podczas Forum Ekonomicznego w Krynicy.

Obecnie w skład indeksu wchodzi 114 najbardziej płynnych spółek notowanych na rynkach giełd w Warszawie, Pradze, Budapeszcie, Zagrzebiu i Bukareszcie. Perspektywę dołączenia widzą także giełdy w Bratysławie i Lublanie. W ten sposób Inicjatywa Trójmorza zyskała narzędzie, które może pomóc w osiągnięciu rozpoznawalności i atrakcyjności w oczach inwestorów. Należy pamiętać, że indeksy giełdowe są wskaźnikami obrazującymi tendencje występujące na danych rynkach. CEEplus dostarczy zatem miarodajnej wiedzy o potencjale państw Trójmorza ${ }^{10}$.

Szansą dla Inicjatywy jest współpraca w dziedzinie energetyki, której podstawowy cel wiąże się ze zwiększeniem bezpieczeństwa energetycznego regionu poprzez dywersyfikację źródeł energii. Inicjatywa wpisuje się w założenia wspólnej polityki energetycznej Unii Europejskiej, zwiększa też szansę

Zob.: D. Héji, The Three Seas Initiative..., s. 129-130.

10 M. Gołębiewska, Indeks giełdowy państw Inicjatywy Trójmorza walczy o dużą stawkę, „Komentarze IEś” 2020, nr 116 (19/2020), „IESLublin. pl” [online], 10 II 2020 [dostęp: 6 VII 2020], dostępny w internecie: <https://ies.lublin.pl/komentarze/ indeks-gieldowy-panstw-inicjatywy-trojmorza-walczy-o-duza-stawke-116-19-2020 >. 
na budowanie nowych szlaków tranzytowych. Kiedy Europa Zachodnia budowała lub modernizowała systemy przesyłowe, to Europa ŚrodkowoWschodnia nie miała takich możliwości. Opóźnienia w tym zakresie są trudne do samodzielnego nadrobienia, ale we współpracy i wzajemnej koordynacji projektów prace powinny posuwać się naprzód zdecydowanie sprawniej. Jest to czynnik sprzyjający integracji w ramach TSI, choć należy zachować tu pewną dozę sceptycyzmu.

W maju 2020 r. Węgry przyłączyły się do Funduszu Inicjatywy Trójmorza (Three Seas Initiative Investment Fund), którego celem jest finansowe wsparcie strategicznych inwestycji TSI w obszarach infrastruktury transportowej, energetycznej oraz cyfrowej. Decyzja ta została nieprzypadkowo zakomunikowana $\mathrm{w}$ czasie wizyty ówczesnego szefa polskiej dyplomacji Jacka Czaputowicza w Budapeszcie (28 v 2020 r.). Polska bowiem jest postrzegana jako główny inicjator i animator pogłębienia współpracy w ramach TSI. Kwota, którą węgierskie władze zaproponowały jako wkład do Funduszu, to 20 mln euro. Znamienne, że niespełna tydzień później, gdy Orbán jako premier Węgier złożył pierwszą wizytę w stolicy Białorusi, Mińsku, zarazem poinformował o utworzeniu linii kredytowej w Exim Banku w związku z zamiarem pogłębienia współpracy między firmami z Węgier i Białorusi. Wartość tego kredytu jest dwukrotnie wyższa od wkładu do Funduszu Trójmorza.

Węgrzy uważają, że sukces gówarantują te przedsięwzięcia, które nie mają charakteru antyrosyjskiego, antychińskiego i (paradoksalnie) antyunijnego. Są to także inicjatywy niepreferujące dominującego znaczenia jednego z państw TSI (głównie Polski). Związane jest to $\mathrm{z}$ aspiracjami Węgier do budowania znaczącej pozycji $\mathrm{w}$ regionie, pewnego pomostu między Wschodem a Zachodem (co niejako wpisuje się w założenia „otwarcia na Wschód”).

\section{Czynniki utrudniające integrację w ramach Trójmorza}

Przyjmując pewne uproszczenie, do czynników utrudniających kooperację w ramach TSI trzeba zaliczyć wszelkie działania, które są wprost antyrosyjskie; w dużej mierze stanowisko węgierskich władz wobec TSI jest determinowane właśnie relacjami węgiersko-rosyjskimi.

Gorzką niejako tradycją stał się fakt, że w pobliżu wyznaczonych dat Szczytów Inicjatywy Trójmorza dochodzi do ważkich spotkań węgiersko- 
-rosyjskich na różnych szczeblach. W przeddzień szczytu w Warszawie udał się do Moskwy minister Szijjártó, gdzie podpisano porozumienie dotyczące tworzenia nowych szlaków gazowych na Węgrzech. Dokument ten ostatecznie potwierdził zaangażowanie Węgier w budowę projektu Gazociągu Turkish Stream. Rok później, 19 września 2018 r., dzień po zakończeniu szczytu w Bukareszcie, Orbán udał się na oficjalne spotkanie z prezydentem Federacji Rosyjskiej Władimirem Putinem. Do najważniejszych ustaleń powziętych wtedy w Moskwie należało podpisanie nowej umowy gazowej obowiązującej do $2020 \mathrm{r}$. W kontrakcie tym zabezpieczono dodatkowe $2 \mathrm{mld} \mathrm{m}^{3}$ gazu pobieranego od strony Austrii. Wydaje się pewne, że gaz ten miałby pochodzić z Gazociągu Północnego Nord Stream. W czasie wizyty Putina w Budapeszcie 30 października 2019 r., premier Rosji stwierdził, że przyłączenie Węgier do Turkish Stream leży w interesie narodowym Budapesztu. W odpowiedzi Orbán informował, że Węgry dlatego przyłączą się do Turkish Stream, ponieważ decyzja o dostawie rosyjskiego gazu wyłącznie gazociągiem przez terytorium Ukrainy jest dla jego kraju wiadomością złą. Po raz kolejny uznano, że niezależnie jaką trasą, rosyjski gaz winien na Węgry płynąć nieprzerwanie ${ }^{11}$.

Obecna umowa gazowa z Rosją wygaśnie w październiku $2021 \mathrm{r}$. Władze węgierskie w związku z tym co jakiś czas przypominają o swojej niezależności energetycznej, o dywersyfikacji źródeł dostaw. Tworzy to złudne wrażenie reorientacji polityki Budapesztu wobec Moskwy. Moim zdaniem jest to wyłącznie budowanie pozycji negocjacyjnej przed rozmowami z Gazpromem na temat wydłużenia umowy gazowej. Paradoksem jest, że przystąpienie Węgier do Europejskiego Zielonego Ładu umożliwia jeszcze większe uzależnienie energetyczne od surowców rosyjskich i innych dostaw z tamtego kierunku. Nowy bilans energetyczny Węgier, który przewiduje osiągnięcie neutralności klimatycznej, opiera się na trzech filarach - atomie z elektrowni atomowej w Paks (która rozbudowana zostanie z kredytu udzielonego przez rosyjskie władze), gazie (w znaczącej ilości pochodzenia rosyjskiego) oraz energii słonecznej. Oznacza to, że dane odnoszące się do uzależnienia energetycznego od Rosji są odwrotnie proporcjonalne do deklaracji w sprawie odzyskiwania niezależności energetycznej.

Jednym $\mathrm{z}$ podstawowych kryteriów funkcjonowania Inicjatywy Trójmorza jest dywersyfikacja dostaw gazowych; tymczasem węgierska 
polityka podejmuje działania absolutnie sprzeczne z tymi założeniami. Gotowość partycypowania w przedsięwzięciach zmniejszających zależność energetyczną od Moskwy pozostaje wciąż w sferze retorycznej. Od lat przedstawiciele państwa węgierskiego podkreślają, że są i pozostają skazani na dostawy z Rosji, pozostali bowiem partnerzy nie wywiązują się z zobowiązań infrastrukturalnych zapewnienia dostaw głównie gazu. Dotyczy to zwłaszcza Chorwacji (terminal LNG na wyspie Krk) oraz Rumunii. Węgrzy wykazują także zainteresowanie eksploatacją złoża Domino-1 w Rumunii. Umożliwiłoby to import gazu z państwa Trójmorza, a także możliwość zacieśnienia relacji z USA. W połowie czerwca spółka LNG Croatia, która realizuje projekt terminalu pływającego LNG na wyspie Krk, poinformowała „o niemal pełnej rezerwacji zdolności regazyfikacyjnych obiektu (wynoszących 2,6 $\mathrm{mld} \mathrm{m}^{3}$ ) na lata 2021-2023 i przekroczeniu progu rentowności na poziomie 75 proc. w kolejnych czterech latach"12. Mateusz Seroka zauważa, że:

kluczowe dla rentowności terminalu było przekonanie spółek na Węgrzech do odbioru gazu pochodzącego z tej inwestycji. Budapeszt zdecydował się na taki krok z powodów ekonomicznych i politycznych. Z uwagi na niskie ceny LNG na światowych rynkach pozyskiwany stąd gaz będzie konkurencyjny cenowo. Ponadto odbiór surowca z chorwackiego terminalu przez węgierskie spółki zmniejszy krytykę Waszyngtonu odnośnie do zbyt bliskich relacji Budapesztu i Moskwy, a także zaanǵażowania Węgier w budowę europejskiej nitki gazociągu TurkStream. Wciąż otwarta pozostaje dyskutowana od 2019 r. kwestia ewentualnego wejścia węgierskich spółek w strukturę własności terminalu, co rozstrzygnie się po przedterminowych wyborach parlamentarnych w Chorwacji (5 lipca).

Należy ponadto zwrócić uwagę, że koncern węgierski MOL jest właścicielem chorwackiej INY. Umożliwia to podejmowanie działań, których efektem może być wręcz destabilizacja rynku energii w Chorwacji. Wciąż trudno znaleźć racjonalne przyczyny, dlaczego Węgry miałyby zrezygnować

12 M. Seroka, Chorwacja: dobre perspektywy terminalu LNG na wyspie Krk, Ośrodek Studiów Wschodnich [online], 24 VI 2020 [dostęp: 6 VII 2010], dostępny w internecie: <https://www.osw.waw.pl/pl/publikacje/analizy/2020-06-24/chorwacja-dobreperspektywy-terminalu-lng-na-wyspie-krk $\rangle$. 
z rosyjskiego gazu, gdy jego cena w przyszłości okaże się bardzo konkurencyjna. Można także wyobrazić sobie sytuację, w której węgierskie władze zaczną blokować przepustowość chorwackiego gazoportu, działając na rzecz rosyjskich interesów.

Kontekst relacji amerykańsko-węgierskich nie jest aż tak istotny, by miał wpływać na relacje węgiersko-rosyjskie, tym bardziej że w przeddzień ważnej dla premiera Orbána wizyty w Białym Domu (maj 2019) do stolicy Węgier przyleciał szef Rosatomu, Aleksiej Lichaczow. Rosatom jest głównym wykonawcą rozbudowy elektrowni atomowej w Paks. W komunikacie, który został opublikowany już po spotkaniu, podano, iż premier Węgier zapewnił szefa Rosatomu, „że rozbudowa elektrowni Paks nie jest zagrożona, a realizacja inwestycji leży w strategicznym interesie Węgier" ${ }^{\text {"13 }}$. W przeddzień wizyty w Waszyngtonie zapewnił partnerów w Moskwie, że nie jest przewidywana żadna gwałtowna zmiana w polityce energetycznej Węgier. Co więcej, po raz kolejny pokazano, że w zasadzie każde ważniejsze spotkanie dotyczące poruszanych zagadnień poprzedzone jest konsultacjami albo w Moskwie, albo z ważniejszymi rosyjskimi oligarchami lub politykami w Budapeszcie.

Istotnym czynnikiem, który może determinować stosunek Węgier do TSI, jest kooperacja z Chinami i rywalizacja (w domyśle z Polską) o tworzenie swoistego hubu inwestycyjnego w rejonie Europy Środkowej. Chodzi tutaj o rozwijanie współpracy transportowej - zarówno drogą lotniczą, jak i kolejową w ramach Nowego Jedwabnego Szlaku. Z racji centralizacji procesu decyzyjnego na Węgrrzech, a także całkowicie przewidywalnej polityki, która od ponad dekady nie ulega zasadniczym przemianom, przyciąganie kapitału chińskiego odbywa się powolnie, ale i sprawnie. Atrakcyjność Węgier wzrosła także po tym, gdy polskie władze odstąpiły od projektu budowy tzw. suchego portu w pobliżu Łodzi, który miał obsługiwać połączenie kolejowe z Chengdu w Chinach. Rozbudowywany jest również hub lotniczy w Budapeszcie. Kiedy na Węgry z ofertą lotów transatlantyckich wchodziły Polskie Linie Lotnicze LOT, ich prezes w swoim wystąpieniu podkreślał, że port lotniczy w Budapeszcie znajduje się $\mathrm{w}$ miejscu, do którego z każdego niemal punktu na Węgrzech można dojechać w ciągu dwóch godzin. W zasięgu tego portu mieszka $8 \mathrm{mln}$ potencjalnych 
pasażerów. Ewentualne ograniczenia w rozwoju węgierskiego hubu mogą być wynikiem wciąż trwających rozmów na poziomie zarówno rządu, jak i samorządu, dotyczących zmniejszenia przepustowości lotniska ze względu na uciążliwość, jaka wiąże się $\mathrm{z}$ operacjami lotniczymi prowadzonymi z Budapesztu ${ }^{14}$. Przypomnieć jednak należy, że inwestycje w porcie lotniczym w Budapeszcie są już w toku, podczas gdy zamysł Centralnego Portu Komunikacyjnego wciąż pozostaje w sferze projektowej i może ulec weryfikacji w związku z następstwami rozwijającej się pandemii coviD-19.

Węgry nie są państwem, które jest przewidywalnym partnerem $\mathrm{w}$ ramach TSI. Węgierska dyplomacja sojusze gospodarcze czy polityczne traktuje w sposób wybiórczy, nie kierując się jakimikolwiek ideami czy sentymentami. Dostrzec też można, że węgierskie władze bardzo ostrożnie zwiększyły zainteresowanie kooperacją w ramach TSI, czego dowodem jest ich finansowy akces do Funduszu Trójmorza. W komunikacie węgierskiego rządu, opublikowanym przy okazji deklaracji przystąpienia do Funduszu, pojawiła się propozycja dotycząca konieczności utworzenia stałego sekretariatu TSI z siedzibą w Budapeszcie. Przedsięwzięcie to mogłoby zwiększyć możliwości zamierzeń oraz wzmocnić ciągłość, koordynację i wymianę informacji między zainteresowanymi państwami Inicjatywy Trójmorza ${ }^{15}$. Należy mieć jednak wzgląd na to, że umiejscowienie jakichkolwiek instytucji powiązanych z TSI w Budapeszcie - z powodu zaangażowania Węgier w przedsięwzięcia sprzeczne $\mathrm{z}$ duchem TSI - byłoby błędem. Gestem dobrej woli węgierskich władz, który mógłby sugerować poważniejsze zaangażowanie Węgier w cały projekt, byłoby powołanie czy to w kancelarii premiera, czy w ministerstwie spraw zagranicznych i handlu zagranicznego pełnomocnika ds. Inicjatywy Trójmorza.

Można przyjąć, z dużą dozą prawdopodobieństwa, że w spotkaniu w Tallinie prezydent Węgier wziął udział ze względu na konferencyjny

14 Na temat planów inwestycyjnych lotniska w Budapeszcie zob.: B. Kaczmarek, Hub budapeszteński jako konkurencja dla Centralnego Portu Komunikacyjnego, Fundacja Republikańska [online], 14 VIII 2020 [dostęp: 1 X 2020], dostępny w internecie: <https://fundacjarepublikanska.org/hub-budapesztenski-jako-konkurencja-dlacentralnego-portu-komunikacyjnego/>.

15 Magyarország továbbra is elkötelezett a Három Tenger Kezdeményezés sikere iránt, Magyarország Kormány [online], dostępny w internecie [dostęp: 7 VII 2020]: <https://www.kormany.hu/hu/kulgazdasagi-es-kulugyminiszterium/hirek/magyarorszag-tovabbra-is-elkotelezett-a-harom-tenger-kezdemenyezes-sikere-irant $\rangle$. 
tryb szczytu. Forma ta uniemożliwiała nieobecność węgierskiego przywódcy, chociaż z dużym przekonaniem można byłoby uznać, że tego typu postawę wybrałyby węgierskie władze. Mimo formalnej obecności János Áder nie uczestniczył w debacie prezydenckiej, która odbyła się w trakcie szczytu. Głos zabrał dopiero w czasie podsumowującego go panelu. W jedynej depeszy agencyjnej dotyczącej Szczytu TSI w Estonii (temat był nieobecny nawet w mediach prorządowych) prezydent wskazywał, że:

współpraca w ramach TSI nie powinna skupiać się wyłącznie na kooperacji w obszarze energetyki, infrastruktury czy cyfryzacji. Zwrócił uwagę na problem śmieci, zanieczyszczonych rzek i trudności z dostępem do wody. Rzeki to naturalne dobro Europy, niestety są stale zanieczyszczane odpadami komunalnymi, poprzemysłowymi, a także rolniczymi. Zalegają w nich również tworzywa sztuczne ${ }^{16}$.

Niewątpliwie zagadnienia związane $\mathrm{z}$ ekologią i przeciwdziałaniem zmianom klimatycznym są niezwykle ważne, znamienne jest jednak to, że prezydent Węgier systematycznie unika wyrażania jasnych opinii odnośnie do bezpieczeństwa energetycznego czy cyfrowego, które stanowią jeden z priorytetów integracji w ramach Trójmorza. Ekologia jest tematem „bezpiecznym", zaangażowanie w nią nie skutkuje opowiedzeniem się w jakikolwiek sposób w kontrze do Federacji Rosyjskiej, będącej jednym z najważniejszych partnerów politycznych Węgier. Oznacza to, że wycofana pozycja Budapesztu, mimo przystąpienia do Funduszu Inicjatywy Trójmorza, pozostaje de facto niezmienna, chociaż można dostrzec pewne delikatne oznaki dotyczące zwiększenia zainteresowania Trójmorzem zarówno na poziomie politycznym, jak i think tanków.

\section{Bibliografia}

Barabás J. T., A Három Tenger Kezdeményezés a 2018, szeptemberi Bukaresti értekezlet után. The Three Seas Initiative after the Bucharest summit of september 2018, , $\mathrm{KKI}$ ELEMZÉSEK" E-2018/34 [online], dostępny w internecie [dostęp: 6 VII 2020]: $\langle$ https://kki.hu/assets/upload/34_KKI-elemzes_TSI_Barabas_20181016.pdf $\rangle$.

16 D. Héjj, Węgry wobec Szczytu Inicjatywy Trójmorza w Tallinie, „Komentarze IEś" 2020, nr 275 (178/2020) [online], 24 X 2020 [dostęp: 6 XI 2020], dostępny w internecie: $<$ https://ies.lublin.pl/komentarze/wegry-wobec-szczytu-inicjatywy-trojmorzaw-tallinie-275-178-2020 $>$. 
Gołębiewska M., Indeks giełdowy państw Inicjatywy Trójmorza walczy o duża stawkę, „Komentarze IEś” 2020, nr 116 (19/2020), IESLublin.pl [online], 10 II 2020 [dostęp: 6 VII 2020], dostępny w internecie: <https://ies.lublin.pl/ komentarze/indeks-gieldowy-panstw-inicjatywy-trojmorza-walczy-o-duzastawke-116-19-2020>.

Héjj D., Trójmorze - nowy instrument w polskiej polityce zagranicznej, „Polski Przegląd Dyplomatyczny" 2017, nr 4.

Héjj D., The Three Seas Initiative in the foreign affairs policy of Hungary, „Rocznik Instytutu Europy Środkowo-Wschodniej" 2019, t. 17, z. 3. DOI: 10.36874/RIESW. 2019.3.7.

Héjj D., Węgry wobec Szczytu Inicjatywy Trójmorza w Tallinie, „Komentarze IE Ś" 2020, nr 275 (178/2020) [online], 24 X 2020 [dostęp: 6 XI 2020], dostępny w internecie: <https://ies.lublin.pl/komentarze/wegry-wobec-szczytu-inicjatywytrojmorza-w-tallinie-275-178-2020 >.

Kaczmarek B., Hub budapeszteński jako konkurencja dla Centralnego Portu Komunikacyjnego, „Fundacja Republikańska” [online], 14 VIII 2020 [dostęp: $1 \mathrm{X}$ 2020], dostępny w internecie: <https://fundacjarepublikanska.org/hub-budapesztenski-jako-konkurencja-dla-centralnego-portu-komunikacyjnego/> .

Komunikat Węgierskiej Agencji Prasowej, MTI [online], 18 IX 2018 [dostęp: 6 VII 2020], dostępny w internecie: 〈https://archiv1988tol.mti.hu/Pages/HirSearch.aspx>.

Magyarország továbbra is ellötelezett a Három Tenger Kezdeményezés sikere iránt, Magyarország Kormány [online], dostępny w internecie [dostęp: 7 VII 2020]: <https://www.kormany.hu/hu/kulgazdasagi-es-kulugyminiszterium/hirek/magyarorszag-tovabbra-is-elkotelezett-a-harom-tenger-kezdemenyezes-sikere-irant $>$.

PappZs., Óriási bukta a keleti, „Népszava” [online], 17 VIII 2018 [dostęp: 6 VII 2020], dostępny w internecie: 〈https://nepszava.hu/3046858_oriasi-bukta-a-keleti-nyitas〉.

Seroka M., Chorwacja: dobre perspektywy terminalu LNG na wyspie Krk, Ośrodek Studiów Wschodnich [online], 24 VI 2020 [dostęp: 6 VII 2020], dostępny w internecie: <https://www.osw.waw.pl/pl/publikacje/analizy/2020-06-24/chorwacja-dobreperspektywy-terminalu-lng-na-wyspie-krk $>$.

Tölgyesi B., A Három tenger kezdeményezés és az Intermarium koncepció háttere és kilátásai. The background and perspectives of the Three Seas Initiative and the Intermarium Concept, „KKI-elemzések” E-2017/30 [online], dostępny w internecie [dostęp: 6 VII 2020]: 〈https://kki.hu/assets/upload/30_KKI-elemzes_POL_ Tolgyesi_20171121.pdf $>$. 